close enough to provide a rich source of fine inorganic sediment, so the carbon date of $14,700 \pm 290$ years B.P. for sample I-556, which came from the bottom $0.2 \mathrm{~m}$. of organic lake mud, should provide a minimum date that is very close to the true date of deglaciation of the locality. This is the first piece of direct evidence to show that fifteen thousand years ago, while the Wuirm glacier in Europe and the Wisconsin glacier in America were going through a halting retreat from their southern limits, the equatorial African mountain glaciers were retreating as well. It strongly supports palynological studies (Martin, P., personal communication, and refs. 3 and 4 ) indicating that Pleistocene climatic changes in the tropics have been of the same sign as those in the rest of the world and synchronous with them.

I thank the John Simon Guggenheim Memorial Foundation and the National Science Foundation for financial support for this work.

Department of Zoology,

D. A. Livinastone

Duke University, Durham,

North Carolina.

${ }^{1}$ Nilsson, E., Geografiska Annaler, 13, 249 (1931).

${ }^{2}$ de Heinzelin, J., Explor, du Parc Nat. Albert, 2ième Sér., 1, 1 (1953). ' van der Hammen, Th., Ann. N.Y. Acad. Sci., 95, 1, 676 (1961).

- Bakker, E. M. van Zinderen, Nature, 194, 201 (1962).

\section{Palygorskite in Leicestershire}

CURRENT geological investigations into the ancient rocks of Leicestershire have revealed three occurrences of the clay mineral palygorskite. These are in the lower quarry at Bardon Hill, the Cliffe Hill quarry and the Warren quarry at Enderby. At all three localities the palygorskite is present in joints in dioritic rocks. In every case its identification has been checked by $X$-ray powder techniques. No sepiolite lines were detected on any of the powder photographs.

At Bardon Hill the palygorskite is found as compact, fibrous masses filling the centre of a joint, the walls of which are lined with coarse calcite crystals. At Cliffe Hill and in a deeply penetrating joint at Enderby, the mineral forms fine specimens of mountain leather and in both cases is intergrown with finegrained calcite. Elsewhere in the Warren quarry at Enderby palygorskite is almost ubiquitous on the joint surfaces of the upper level, where it is free from carbonate impurities and again takes the form of compact, fibrous masses. At all three localities the paly. gorskite occurs at levels not far below the overlying Triassic unconformity and in the Warren quarry it can be traced, without a break, from the joints in the diorite into the matrix of the overlying basal Triassic breccia.

Palygorskites found in igneous rocks (usually in joints or crush bands) are generally considered to be of hydrothermal origin ${ }^{1,2}$. When found in sediments the mineral is assumed to be of sedimentary origin ${ }^{8,4}$. So far as the Leicestershire localities are concerned the geological similarities of the three occurrences suggest that the palygorskite in each is of the same age and origin. With regard to the origin, the palygorskite at Fnderby cannot have been deposited from a hydrothermal differentiate of the dioritic magma since it is found in the overlying Triassic rocks. We believe that it was deposited from downward-moving waters which were in direct connexion with the lakes and rivers in which the basal Triassic sediments of the area were deposited and not from post-Triassic ascending hydrothermal solutions.

The following observations at Enderby are in agreement with this conclusion. (1) Palygorskite is only found on the second (deeper) level in strong joints which persist upwards to the Triassic unconformity. (2) Its main development is in joints within approximately thirty feet of the unconformity. (3) The mineral is most abundant in the area below wadies. (4) It is poorly developed in, or absent from, adjacent, buried hills which would have acted as anticlinal traps for ascending solutions. It is of interest to note here that in Charnwood Forest a number of other mineral veins with calcite, barytes and clay minerals occur in joints in the Charnian rocks. These can be traced upwards into Triassic sediments where the minerals concerned form parts of the matrices of the basal breccias.

In view of this conclusion, we suggest that occurrences of palygorskite in the joints of igneous rocks should not, without supporting evidence, be assumed to be of hydrothermal origin. Further, having noted that palygorskite is frequently reported from continental deposits and soils (often red) (3,5-7, $^{3}$ we propose that occurrences such as those in the Shetland Isles ${ }^{2}$ and some of the others reported from various parts of Scotland ${ }^{8}$ may point to the former existence of Old Red Sandstone or Triassic unconformities at no great height above the points at which palygorskite is now found.

\section{A. M. Evans \\ R. J. KING}

Department of Geology,

University of Leicester.

${ }^{1}$ Caillere, S., C.R. Acad. Sci., Paris, 238, 697 (1951).

"Stephen, I., Miner, Mag., 30, 471 (1954).

3 Rogers, L, E., Martin, A, E., and Norrish, K., Miner. Mag., 30 D84, (1954).

‘ Zkhus, I. D., Doklady Acad. Sci. D.S.S.R., 107, 784 (1956).

Michaud, R., Cerighelli, R., and Drouineau, G., C.R. Acad, Sci. Paris, 228, 94 (1945).

- Muir, A., J. Soil. Sci., 2, 168 (1051).

'Heystek, H., and Schmidt, E. R., Trans. Geol. Soc., South Africa, 56,99 (1954).

8 Heddle, M. F., The Mineralogy of Scotland, 2, 151 (1801).

\section{Geochemical Characteristics of Carbon- atites}

The lava from Fort Portal in western Uganda, recently described by von Knorring and $\mathrm{Du}$ Bois ${ }^{1}$, was considered to be carbonatitic in view of the high carbonate content and its agreement with the characteristic trace element pattern as observed among true carbonatites, which are in the main calcitic or dolomitic rocks. In pure carbonatite rocks, significant elements like iron, titanium, zirconium and niobium may be accidental or regional to some degree, whereas elements like strontium, barium, rare earths and phosphorus seem to belong to the earlier (primary) constituents of carbonatite magmas.

An examination of another carbonatite lava, collected from the crater of Oldonyo Lengai volcano in Tanganyika by Dr. N. J. Guest, shows a remarkable composition which may correspond more closely to some of the primary carbonatite magmas. Chemically this lava is composed of sodium, calcium and potas. sium as major constituents, chlorine, fluorine, sulphur, phosphorus, strontium, barium, manganese and iron as minor, whereas other elements are present in amounts less than 1,000 p.p.m. When finely crushed, about 67 per cent of this lava is soluble in hot water 